\title{
Risk-Taking Behavior Of Public Pension Plans Before And After The Financial Crisis Of 2008
}

Youngkyun Park, University of Idaho, USA

\begin{abstract}
This paper investigates whether public pension plans' risk-taking behavior has changed after the recent financial crisis of 2008 by testing two contrasting hypotheses on pension funding: risk transfer and risk management hypotheses. In managing pension assets, public pension plan sponsors may have an incentive for risk transfer because underfunded pension obligations can be shifted to future taxpayers (risk transfer hypothesis). Facing a budget constraint, they may also have an incentive for risk management because they would prefer to stabilize their contributions (risk management hypothesis). Using a sample of 126 public pension plans for the period of 2001-2011, this paper finds that public pension plans' risk-taking behavior has changed after the financial crisis of 2008. Before the financial crisis, public pension plan sponsors invest more in equities when a large required contribution is expected, which is consistent with the risk transfer hypothesis. After the financial crisis, however, the plan sponsors invest less in equities when a large required contribution is expected, which is consistent with the risk management hypothesis. The findings suggest that public pension plans' risk-taking behavior is not constant over time, but can be varied depending on market conditions.
\end{abstract}

Keywords: Public Pension Plan; Risk Management; Risk Transfer

\section{INTRODUCTION}

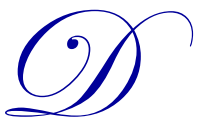

uring the recent financial crisis of 2008, public-sector pension plans experienced large declines in the value of their investment portfolios. For 101 public pension plans, the market value of pension assets in fiscal year 2009 ending on June 30 dropped by about $25 \%$ to $\$ 2.1$ billion from $\$ 2.8$ billion in fiscal year 2007 ending on June 30 (Brainard, 2008, 2010). The declines in the value of public pension assets have brought attention to several issues, such as funding status, the rates of return used to discount plan liabilities (known as the "discount rate"), and investment strategies (Government Accountability Office [GAO], 2010a). And given public-sector plan sponsors' limited ability to increase employee contributions, increasing deficits in pension plans has raised the probability that employer contributions will have to be made to make up for the deficits (GAO, 2010b).

Public plan sponsors have sought stabilizing their contributions to the plans using actuarial methodologies. In particular, in order to maintain a stable contribution as a percentage of payroll over time, plan sponsors have adopted a smoothing period for investment losses and an amortization period for unfunded accumulated liability (Munnell, Aubry, \& Muldoon, 2008). However, responding to increasing required contributions to the plans as a consequence of underfunding, plan sponsors may invest more in high risk assets, such as equities, with an expectation that earnings from the investment would reduce the required employer contributions. This risk-taking behavior of public pension sponsors has been supported by the findings of recent studies on public pension plans (e.g., Pennacchi \& Rastad, 2011; Mohan \& Zhang, 2012).

However, after experiencing a significant underfunding during the financial crisis of 2008, public pension plans' risk-taking behavior may be changed. For example, according to the Public Fund Surveys covering 126 plans, 
the average allocation to equities in fiscal year 2009 dropped to $52.1 \%$ from $59.7 \%$ in fiscal year 2007, while the average allocation to fixed income in fiscal year 2009 increased to $29.0 \%$ from $26.6 \%$ in fiscal year 2007 (Brainard, 2008, 2010). This paper examines whether public pension plans' risk-taking behavior has changed after the recent financial crisis by testing two contrasting hypotheses on pension funding: risk transfer (e.g., Sharpe, 1976; Treynor, 1977; Epple \& Schipper, 1981; Inman, 1982; Gold, 2003) and risk management (Rauh, 2009) hypotheses. For the examination, the paper uses the recent data from the Public Plans Database (PPD) maintained by the Center for Retirement Research at Boston College.

To test the two hypotheses, this study investigates a relationship between an employer contribution gapthe difference between the projected annual required contribution and actual employer contribution as a percentage of payroll-in the previous period and the asset allocation in the current period. Prior studies on public pension plan asset investments focus on a relationship between a funding ratio (defined by a ratio of pension asset over pension liability) in the previous period and the asset allocation in the current period (e.g., Pennacchi \& Rastad, 2011; Mohan \& Zhang, 2012). However, the funding ratio may not directly affect public pension plans' risk-taking behavior because the funding ratio can be affected by different assumptions on pension assets (e.g., market or actuarial value of pension assets) and/or pension liabilities (e.g., different discount rates). Different from the funding ratio, the employer contribution gap may directly affect the risk-taking behavior of public pension plans; a large employer contribution gap may need to be resolved by increasing employer contributions, but the plan sponsor may be able to reduce the required employer contributions by investment earnings. Thus, an employer contribution gap in the previous period may affect more directly the plan sponsor's risk-taking behavior in managing pension assets in the next period than a funding ratio in the previous period.

While controlling for plan fixed effects, I find evidence that the risk-taking behavior of public pension plan sponsors has changed after the financial crisis. The risk transfer hypothesis is supported in the pre-crisis period, which is consistent with the findings of Pennacchi and Rastad (2011) and Mohan and Zhang (2012). However, the risk management hypothesis is supported in the post-crisis period, which is consistent with the finding of Rauh (2009) with corporate pension plans. This study extends the extant literature on public pension funding by presenting that the risk-taking behavior of public pension plans has changed to risk management from risk transfer after the financial crisis. This finding may suggest that public pension plans' risk-taking behavior is not constant over time, but can be varied depending on market conditions.

The remainder of the paper is organized as follows. Section 2 provides a brief review on public pension benefit funding as institutional background. Section 3 addresses two hypotheses related to risk-taking behavior of public pension plans. Section 4 describes data and model specification to test the hypotheses. Section 5 presents empirical results. Section 6 concludes the paper.

\section{INSTITUTIONAL BACKGROUND: PUBLIC PENSION BENEFIT FUNDING}

Different from private-sector defined benefit plans, public pension plans are not funded entirely by employers; they are financed by employees as well as employers. Public pension revenue relies on three sources: earnings from investments, government (employer) contributions, and employee contributions. Among these sources of income, investment earnings typically have accounted for the largest portion of plan funding because public pension plans are generally financed on a funded basis rather than a pay-as-you-go basis. On average from 1982 to 2010, 61\% of public pension benefit payments are funded through investment earnings, $26 \%$ from employer contributions, and 13\% from employee contributions (National Association of State Retirement Administrators [NASRA], 2013). Since public pension funding depends largely on investment earnings, negative (positive) returns on investments decrease (increase) the funding status of pension plans. Sharp improvements or reductions in funding status, however, are gradually recognized in financial statements because of the use of a smoothing period (usually five years), which is applied as a way to minimize sharp swings in annual funding requirements and stabilize plan sponsors' contributions over time (e.g., Munnell et al., 2008).

Although public pension plans are not subject to ERISA's funding standards, they usually follow the guidelines specified in Governmental Accounting Standards Board Statement (GASB). In particular, GASB Statement No. 25 addresses that states should make annual required contributions (ARC) that include the normal cost - the cost of benefits accruing in the current year — and amortized payments for unfunded actuarial accrued 
liability (unfunded actuarial liability). However, states do not always contribute enough funds to cover the ARC. For example, according to the recent data from Public Plans Database (PPD), 58 plans out of 125 public pension plans fully funded their required contributions in fiscal year 2010. Among the remaining plans that did not meet their required contributions, 11 plans contributed less than $50 \%$ of the required contributions.

As another parameter that can affect pension funding, GASB Statement No. 27 specifies that the expected long-term rate of return on pension assets should be used as a discount rate for the evaluation of pension liability. The investment return assumption directly affects employer required contributions through its impact on anticipated asset values, and it also influences the required contributions indirectly through the liability value. A higher investment return assumption (i.e., a higher discount rate for pension liability) would lead to lower ARCs. In fiscal year 2011, most plans (42\% of 126 plans) adopt $8 \%$ as an investment return assumption (a discount rate), but $17 \%$ of the plans use an investment return assumption greater than 8\% (Public Fund Survey, 2012).

\section{LITERATURE REVIEW AND HYPOTHESES}

This section reviews the literature on pension funding in corporate and public pension plans and discusses two hypotheses, risk transfer and risk management hypotheses, for examining public pension plans' risk-taking behavior. To test the two hypotheses, I investigate a relationship between an employer contribution gap- the difference between the projected annual required contribution and actual employer contribution as a percentage of payroll - in the previous period and the asset allocation in the current period. This is different from prior studies (e.g., Pennacchi \& Rastad, 2011; Mohan \& Zhang, 2012) that focus on a relationship between a funding ratio-a ratio of pension asset over pension liability - in the previous period and the asset allocation in the current period.

\subsection{Risk Transfer Hypothesis}

Similar to corporate defined benefit (DB) pension plan sponsors, public pension plan sponsors may have a moral hazard (or risk transfer) incentive in managing pension assets. Corporate pension plan sponsors may have an incentive to invest in risky assets because they are insured by the Pension Benefit Guaranty Corporation (PBGC). For example, Sharpe (1976) and Treynor (1977) argue that moral hazard incentives for firms to underfund pension plans and invest the pension assets in risky securities can be created by firms' efforts to maximize the put option value of the PBGC insurance. For underfunded public pension plans, the government can raise taxes to fund the plans, and as a result, the underfunded pension obligations can be shifted to future taxpayers (Gold, 2003). Thus, facing the unpopular choices of raising taxes to increase employer contributions in the short run, the plan sponsor may increase a share of risky securities in the plan assets because earnings from the investments may reduce the required employer contributions (Bader \& Gold, 2007; Lucas \& Zeldes, 2009). Politicians are "not concerned about long-term funding issues because they operate under a relatively short time horizon" (Giertz \& Papke, 2007, p. 314). Therefore, if the risk transfer hypothesis holds, a positive relation is predicted between the employer contribution gap in the previous period and an equity share of pension assets in the current period.

\subsection{Risk Management Hypothesis}

In a context of corporate DB plans, Rauh (2009) argues that corporate plan sponsors have risk management incentives to avoid costly financial distress in pension fund investing. Unexpected poor performance in pension assets requires the firm to make cash contributions to pension funds, which in turn reduce capital expenditures (Rauh, 2006). Similar to corporate DB plans, unexpected increases in required contributions to public pension plans may reduce services for schools or police, which would correspond to capital expenditures of companies, because the state/municipal budget is fixed in the short run (Mohan \& Zhang, 2012). Because public pension funding relies largely on investment earnings, volatility in financial markets would result in considerable variations in required employer contributions. As public plan sponsors have sought stabilizing their contributions to the plans using actuarial methodologies, they would prefer to have predictable pension contributions. ${ }^{1}$ From this risk management

\footnotetext{
${ }^{1}$ In public pension plans, employer contributions are designed to remain level as a percentage of payroll. For example, most public pension plans are currently valued using the "entry-age normal actuarial cost method." This method is designed to maintain a level contribution as a percentage of payroll over time, and aims to help governments plan and budget their contributions to pension plans (National Conference on Public Employee Retirement System, 2008).
} 
perspective, when public pension plan sponsors recognize a large employer contribution gap between projected and actual employer contributions, they may reduce investment in risky assets, which may result in more variable contributions. Thus, if the risk management hypothesis holds, a negative relation is predicted between the employer contribution gap in the previous period and an equity share of pension assets in the current period.

\subsection{Risk-Taking Behavior Before and After the Financial Crisis of 2008}

For the recent financial crisis of 2008, public-sector pension plans experienced a significant drop in the value of their assets and, thereby, a significant underfunding of the plans. The financial crisis may change the risktaking behavior of public pension plan sponsors. Thus, if there is any change in the risk-taking behavior after the financial crisis, the relation between the employer contribution gap and an equity share of pension assets would change from positive to negative or vice versa.

\section{DATA AND MODEL SPECIFICATION}

This study uses fiscal years 2001 through 2011 from the Public Plans Database (PPD) produced by the Center for Retirement Research at Boston College. The database covers 126 state and local pension plans for 50 states and the District of Columbia. Each state has at least one pension system, and each system can have multiple plans for different employee groups, such as teachers, police and firefighters, and state and local government employees. The public pension plans held $\$ 23.1$ billion pension assets on average at the end of fiscal year $2011 .^{2}$

To test the two hypotheses for the risk-taking behavior of public pension plans, I use the following model:

$$
\begin{aligned}
\text { Equity }_{i, t}= & \text { ErContrGap }_{i, t-1}+\text { InvRet }_{i, t-1}+\text { FundingRatio }_{i, t-1}+\text { ActiveAnnuitant }_{i, t}+\text { PlanSize }_{i, t} \\
& + \text { BoardComp }_{i, t}+\text { Teacher }_{i, t}+\text { General }_{i, t}+\text { InvCouncil }_{i, t}+\text { Year }_{t}+\text { Plan }_{i}+e_{i, t}
\end{aligned}
$$

where

Equity $_{i, t}=$ Equity share of pension plan assets for plan $i$ at time $t$,

ErContrGap $_{i, t-1}=E_{t-1}\left[\right.$ ARC $\left._{i, t}\right]-$ ErContr $_{i, t-1}$,

$E_{t-1}\left[A R C_{i, t}\right]=$ Projected $\mathrm{ARC}_{t}$ as a percentage of payroll for plan $i$ at time $t-1$,

ErContr $_{i, t-1}=$ Actual employer contribution as a percentage of payroll for plan $i$ at time $t-1$,

Funding Ratio $_{i, t-1}=$ Actuarial funding ratio (a ratio of actuarial pension assets over actuarial pension liabilities) for plan $i$ at time $t-1$,

InvRet $_{i, t-1}=$ Investment return assumption (or discount rate) for plan $i$ at time $t$,

ActiveAnnuitant $_{i, t}=$ Ratio of active participants to annuitants for plan $i$ at time $t$,

PlanSize $_{i, t}=$ Natural logarithm of the market value of pension assets for plan $i$ at time $t$,

BoardComp $_{i, t}=$ Ratio of the total plan participants on the board to the total board members for plan $i$ at time $t$,

Teacher $_{i, t}=$ A dummy variable that takes 1 if plan $i$ is a teacher's plan and 0 otherwise at time $t$,

General $_{i, t}=$ A dummy variable that takes 1 if plan $i$ is a general plan that covers public employees excluding teachers and police and firefighters and 0 otherwise at time $t$,

InvCouncil $_{i, t}=\mathrm{A}$ dummy variable that takes 1 if plan $i$ has a separate investment council and 0 otherwise at time $t$.

Equation 1 includes an employer contribution gap (ErContrGap) as one of the key independent variables. A variable of ErContrGap is defined by a gap between projected $A R C_{t}$ at time $t-1$ and actual employer contribution at time $t$-1. A larger employer contribution gap indicates a larger pressure for employer contributions because the plan sponsor would meet larger required contributions in the next period, all other things being equal. In addition, Equation 1 includes the investment return assumption (InvRet) (or discount rate) in the previous period because public pension plans selecting a higher discount rate are more likely to invest in higher risk assets than those who use a lower discount rate (e.g., Park, 2009; Pennacchi \& Rastad, 2011; Mohan \& Zhang, 2012).

\footnotetext{
${ }^{2}$ When the author writes this article, the PPD provides the information on the market value of plan assets for 99 state and local pension plans for fiscal year 2011. The PPD does not include the information for the remaining 27 plans yet.
} 
To test the two hypotheses for public pension plan risk-taking behavior in the pre- and post-financial crisis periods, I estimate Equation 1 for the pre-crisis period (2001-2007) and the post-crisis period (2008-2011). Since an actuarial funding ratio (FundingRatio) would be significantly (negatively) correlated with an employer contribution gap (ErContrGap), I further estimate Equation 1 by different funding levels (low vs. high) for each period to control for potential collinearity between the two variables.

\section{EMPIRICAL RESULTS}

\subsection{Descriptive Statistics}

Table 1 provides summary statistics for all plans during the period of 2001-2011 for key variables. Panel A presents plan characteristics such as actuarial funding ratios, investment return assumptions (or discount rates), actual employer contribution as a percentage of payroll, employer contribution gaps, and other characteristics. The public pension plans in the sample show a funding ratio of $84-85 \%$ on average during the period. A majority of the public pension plans adopt $8 \%$ as an investment return assumption (or a discount rate). Employer contribution gaps show a wide dispersion: the standard deviation is as large as over seven times the mean. The pension plans have a smoothing period of 4 years and an amortization period of about 27 years on average. Teachers' plans account for $31.7 \%$, police and firefighters' plans $9.6 \%$, and general plans $58.7 \%$ of the public pension plans. About $35 \%$ of the plans have separate investment councils.

Table 1: Descriptive Statistics

\begin{tabular}{|c|c|c|c|c|c|c|}
\hline & Mean & Std. Dev. & $\mathbf{P 2 5}$ & Median & P75 & $\mathbf{N}$ \\
\hline \multicolumn{7}{|c|}{ Panel A: Descriptive Statistics of Plan Characteristics } \\
\hline Actuarial funding ratio & 0.843 & 0.166 & 0.741 & 0.854 & 0.972 & 1,313 \\
\hline Investment return assumption & 0.080 & 0.004 & 0.078 & 0.080 & 0.083 & 1,303 \\
\hline $\begin{array}{l}\text { Actual employer contribution (as a percentage } \\
\text { of payroll) }\end{array}$ & 0.106 & 0.121 & 0.051 & 0.083 & 0.122 & 1,241 \\
\hline $\begin{array}{l}\text { Employer contribution gap: Difference } \\
\text { between projected employer annual required } \\
\text { contribution and actual employer contribution } \\
\text { (as a percentage of payroll) }\end{array}$ & 0.044 & 0.322 & 0.003 & 0.023 & 0.064 & 940 \\
\hline Ratio of active participants to annuitants & 3.125 & 7.996 & 1.628 & 2.002 & 2.509 & 1,251 \\
\hline Smoothing period (year) & 4.055 & 2.186 & 3.000 & 5.000 & 5.000 & 1,266 \\
\hline Amortization period (year) & 26.650 & 11.277 & 20.000 & 29.000 & 30.000 & 1,161 \\
\hline Teachers' plan & 0.317 & 0.466 & 0.000 & 0.000 & 1.000 & 1,386 \\
\hline Police/firefighters' plan & 0.096 & 0.294 & 0.000 & 0.000 & 0.000 & 1,386 \\
\hline General plan & 0.587 & 0.492 & 0.000 & 1.000 & 1.000 & 1,386 \\
\hline Separate investment council & 0.349 & 0.477 & 0.000 & 0.000 & 1.000 & 1,386 \\
\hline Market value of plan assets (\$ bil.) & 18.26 & 28.21 & 3.74 & 8.88 & 19.84 & 1,358 \\
\hline \multicolumn{7}{|c|}{ Panel B: Descriptive Statistics of Plan Asset Allocation } \\
\hline Equities & 0.552 & 0.109 & 0.496 & 0.570 & 0.623 & 1,353 \\
\hline Fixed income & 0.283 & 0.097 & 0.229 & 0.266 & 0.330 & 1,353 \\
\hline Real estate & 0.056 & 0.048 & 0.005 & 0.052 & 0.088 & 1,332 \\
\hline Alternatives & 0.036 & 0.063 & 0.000 & 0.000 & 0.051 & 1,325 \\
\hline Cash and short-term assets & 0.023 & 0.030 & 0.003 & 0.014 & 0.032 & 1,332 \\
\hline Other assets & 0.052 & 0.069 & 0.000 & 0.022 & 0.090 & 1,324 \\
\hline
\end{tabular}

Panel B presents plan asset allocation to equities, fixed income, real estate, alternatives (including private equity and hedge funds), cash and short-term assets, and other assets. On average $55.2 \%$ of the plan assets are invested in equities, $28.3 \%$ in fixed income, $5.6 \%$ in real estate, and $3.6 \%$ in alternatives during the period of 2001-2011.

\subsection{Public Pension Plans: Pre- and Post-Financial Crisis}

Table 2 presents whether plan characteristics, asset allocations, and investment return assumptions have changed since the financial crisis of 2008. Panel A shows changes in plan characteristics after the financial crisis. 
The ratio of active participants to annuitants has significantly reduced because of a significant increase in the number of annuitants. The funding status of public pension plans has deteriorated by 10.2 percentage points on average. Actual employer contribution as a percentage of payroll has increased by 2.3 percentage points on average, but the employer contribution gap as a percentage of payroll has rather increased by 5.2 percentage points since the financial crisis. Panel B presents changes in asset allocations after the financial crisis. A share of equities in pension assets has significantly decreased by 7.0 percentage points on average, while a share of fixed income has significantly decreased by 2.2 percentage points on average. In contrast, shares of real estate and alternatives have significantly increased by 1.6 and 4.1 percentage points, respectively. Panel $\mathrm{C}$ presents that more pension plans have adopted a low discount rate (lower than $8 \%$ ) after the financial crisis. Before the financial crisis, $29.6 \%$ of the plans adopted a high discount rate (greater than $8 \%$ ), while $24.9 \%$ adopted a low discount rate (lower than $8 \%$ ). After the financial crisis, however, $23.2 \%$ of the plans adopted a high discount rate, while $33.9 \%$ adopted a low discount rate.

Table 2: Public Pension Plans: Pre- and Post-Financial Crisis

\begin{tabular}{|c|c|c|c|c|c|c|c|c|}
\hline & \multicolumn{3}{|c|}{$\begin{array}{c}\text { Pre-Crisis } \\
(2001 \text { To 2007) }\end{array}$} & \multicolumn{3}{|c|}{$\begin{array}{c}\text { Post-Crisis } \\
(2008 \text { To 2011) } \\
\end{array}$} & \multicolumn{2}{|c|}{$\begin{array}{c}\text { Difference } \\
\text { (= Post - Pre })\end{array}$} \\
\hline & Mean & Median & $\mathbf{N}$ & Mean & Median & $\mathbf{N}$ & Mean & Median \\
\hline \multicolumn{9}{|l|}{ Panel A: Plan Characteristics } \\
\hline $\begin{array}{l}\text { Ratio of active participants to } \\
\text { annuitants }\end{array}$ & 3.589 & 2.145 & 823 & 2.233 & 1.805 & 428 & $-1.356^{* *}$ & $-0.340 * * *$ \\
\hline $\begin{array}{l}\text { Number of active participants } \\
(000 \mathrm{~s})\end{array}$ & 97.43 & 61.39 & 823 & 104.38 & 61.76 & 428 & 6.94 & 0.37 \\
\hline Number of annuitants $(000 \mathrm{~s})$ & 44.18 & 28.04 & 823 & 55.90 & 35.52 & 428 & $11.73 * * *$ & $7.48 * * *$ \\
\hline Actuarial funding ratio & 0.878 & 0.893 & 866 & 0.776 & 0.777 & 323 & $-0.102 * * *$ & $-0.116 * * *$ \\
\hline $\begin{array}{l}\text { Actual employer contribution (as } \\
\text { a percentage of payroll) }\end{array}$ & 0.098 & 0.075 & 817 & 0.121 & 0.098 & 306 & $0.023 * * *$ & $0.023^{* * *}$ \\
\hline $\begin{array}{l}\text { Employer contribution gap (as a } \\
\text { percentage of payroll) }\end{array}$ & 0.024 & 0.020 & 579 & 0.076 & 0.030 & 361 & $0.052 *$ & $0.010 * * *$ \\
\hline $\begin{array}{l}\text { Market value of plan assets } \\
\text { (\$ bil.) }\end{array}$ & 17.63 & 8.79 & 881 & 19.43 & 8.96 & 477 & 1.80 & 0.17 \\
\hline \multicolumn{9}{|l|}{ Panel B: Plan Asset Allocation } \\
\hline Equities & 0.577 & 0.591 & 881 & 0.507 & 0.522 & 472 & $-0.070 * * *$ & $-0.069 * * *$ \\
\hline Fixed income & 0.291 & 0.273 & 881 & 0.269 & 0.256 & 472 & $-0.022 * * *$ & $-0.018 * * *$ \\
\hline Real estate & 0.050 & 0.047 & 865 & 0.066 & 0.060 & 467 & $0.016 * * *$ & $0.013 * * *$ \\
\hline Alternatives & 0.022 & 0.000 & 862 & 0.063 & 0.030 & 463 & $0.041 * * *$ & $0.030 * * *$ \\
\hline Cash and short-term assets & 0.023 & 0.014 & 867 & 0.021 & 0.014 & 465 & -0.002 & 0.000 \\
\hline \multicolumn{9}{|c|}{ Panel C: Investment Return (Discount Rate) Assumption } \\
\hline Plans using an $8 \%$ discount rate & 0.0800 & 0.0800 & $\begin{array}{c}393 \\
(45.5 \%)\end{array}$ & 0.0800 & 0.0800 & $\begin{array}{c}188 \\
(42.8 \%)\end{array}$ & & \\
\hline Plans using a high discount rate ${ }^{\dagger}$ & 0.0843 & 0.0850 & $\begin{array}{c}256 \\
(29.6 \%)\end{array}$ & 0.0838 & 0.0838 & $\begin{array}{c}102 \\
(23.2 \%)\end{array}$ & $-0.0005^{* * * *}$ & $-0.0013 * *$ \\
\hline Plans using a low discount rate ${ }^{\dagger}$ & 0.0742 & 0.0750 & $\begin{array}{c}215 \\
(24.9 \%)\end{array}$ & 0.0745 & 0.0750 & $\begin{array}{c}149 \\
(33.9 \%)\end{array}$ & 0.0002 & $0.0000^{*}$ \\
\hline
\end{tabular}

$\dagger$ A high (or low) discount rate indicates whether a plan's discount rate is greater (or lower) than $8 \%$. Note: A two-sample $t$-test with unequal variances is used to compare the means. A Wilcoxon rank sum test is used to compare the medians. ***, **, and $*$ indicates significance at the $1 \%, 5 \%$, and $10 \%$ levels, respectively.

\subsection{Regression Analysis}

To examine public pension plans' risk-taking behavior in the pre- and post-financial crisis periods, I estimate Equation 1 for the pre-crisis period (2001-2007) and the post-crisis period (2008-2011). Table 3 presents the regression results. Columns (1) and (2) show results for the pre-crisis period, while columns (3) and (4) show results for the post-crisis period. Regarding model specifications, columns (2) and (4) include plan fixed effects, but columns (1) and (3) do not. 
Table 3: Regression Analysis of Public Pension Plan Risk-Taking Behavior: Pre- and Post-Financial Crisis

\begin{tabular}{|c|c|c|c|c|}
\hline \multirow{2}{*}{$\begin{array}{c}\text { Dependent Variable: } \\
\text { Portfolio share of equities at } t\left(\text { Equity }_{t}\right)\end{array}$} & \multicolumn{2}{|c|}{ Pre-Crisis (2001 to 2007) } & \multicolumn{2}{|c|}{ Post-Crisis (2008 to 2011) } \\
\hline & (1) & $(2)$ & (3) & (4) \\
\hline Employer contribution gap at $t-1$ & $0.065 * *$ & $0.028 * *$ & 0.065 & $-0.055 * *$ \\
\hline$\left(\right.$ ErContrGap $\left._{t-1}\right)$ & $(0.030)$ & $(0.013)$ & $(0.055)$ & $(0.021)$ \\
\hline Investment return assumption at $t-1$ & $3.964 * * *$ & 3.094 & -0.396 & -0.176 \\
\hline$\left(\operatorname{InvRet}_{t-1}\right)$ & $(1.493)$ & $(1.980)$ & $(1.476)$ & $(0.826)$ \\
\hline Actuarial funding ratio at $t-1$ & -0.032 & 0.006 & -0.058 & -0.174 \\
\hline (FundingRatio ${ }_{t-1}$ ) & $(0.046)$ & $(0.049)$ & $(0.066)$ & $(0.128)$ \\
\hline Ratio of active participants to annuitants & 0.011 & $-0.017 *$ & -0.003 & -0.019 \\
\hline at $t$ (ActiveAnnuitant A $_{t}$ & $(0.007)$ & $(0.010)$ & $(0.010)$ & $(0.040)$ \\
\hline & 0.010 & -0.055 & -0.005 & $0.152 * * *$ \\
\hline Plan size at $t\left(\right.$ Planslze $\left._{t}\right)$ & $(0.007)$ & $(0.043)$ & $(0.007)$ & $(0.057)$ \\
\hline Board comnosition at $t$ (BoardComn) & $0.076 * *$ & & $0.146 * *$ & \\
\hline Boara composition al $t($ Boaracomp $t)$ & $(0.035)$ & & $(0.060)$ & \\
\hline & 0.030 & & $0.075^{*}$ & \\
\hline leachers plan at $t$ ( leacher $\left._{t}\right)$ & $(0.032)$ & & $(0.044)$ & \\
\hline & 0.039 & & 0.070 & \\
\hline General state plan at $t\left(\right.$ General $\left._{t}\right)$ & $(0.031)$ & & $(0.043)$ & \\
\hline Separate investment council at $t$ & $0.033^{*}$ & & -0.014 & \\
\hline$($ InvCouncil $)$ & $(0.017)$ & & $(0.020)$ & \\
\hline Time fixed effects & Yes & Yes & Yes & Yes \\
\hline Plan fixed effects & No & Yes & No & Yes \\
\hline $\begin{array}{l}\text { Hausman test for model specification: } \\
\text { Prob }>\chi^{2}\end{array}$ & & 0.005 & & 0.009 \\
\hline Number of plans & 85 & 85 & 103 & 103 \\
\hline Number of observations & 463 & 463 & 330 & 330 \\
\hline $\mathrm{R}^{2}$ & 0.237 & 0.244 & 0.166 & 0.164 \\
\hline
\end{tabular}

Note: Numbers in parenthesis are robust standard errors, which are adjusted for plan clusters. $* * *, * *$, and $*$ indicates significance at the $1 \%, 5 \%$, and $10 \%$ levels, respectively.

When plan fixed effects are controlled for, the results show that public pension plan sponsors' risk-taking behavior has changed after the financial crisis of 2008. Employer contribution gap at $t-1$ (ErContrGapt $\left.{ }_{t-1}\right)$ is significantly positively associated with equity allocation at $t\left(\right.$ Equity $\left._{t}\right)$ for the pre-crisis period, whereas the variable is significantly negatively associated with allocations to equities for the post-crisis period. The positive relation between the two variables for the pre-crisis period indicates that public pension plan sponsors tend to increase a share of equities in pension portfolios when the employer contribution gap is widened, supporting the risk transfer hypothesis. In contrast, the negative relation between the two variables for the post-crisis period indicates that the plan sponsors tend to decrease a share of equities when the employer contribution pressure becomes increased, supporting the risk management hypothesis.

A plan's employer contribution gap would be closely related to its funding ratio because a plan's ARC is affected by amortized payments for unfunded actuarial accrued liability as well as employer normal cost. In the sample, the two variables, ErContrGap and FundingRatio, are significantly negatively correlated (Pearson's $r=$ 0.108 with $P$-value $<0.01$ ). Thus, in order to control for potential collinearity between the two variables, Equation (1) is estimated for two different funding levels (low vs. high) for each period. Two funding levels are categorized with a threshold of an $83 \%$ of actuarial funding ratio. The threshold is the mean of the average actuarial funding ratios in the pre- and post-crisis periods. If a plan's funding ratio is greater or equal to $83 \%$, the plan is regarded as one that has a high funding level. Otherwise, a plan is regarded as one that has a low funding level.

Table 4 presents regression results by two different funding levels for each period. For the pre-crisis period, when the employer contribution gap is increased, public pension plans having a low funding level at $t-1$ do not significantly increase their risk-taking behavior at $t$ (columns (1) and (2)). However, those having a high funding level at $t-1$ tend to increase equity allocations at $t$ (columns (3) and (4)). The results indicate that, for the pre-crisis period, the risk-taking behavior of public pension plans that face increasing employer contribution pressure (the risk transfer hypothesis) applies only to the plans in a high funding level, not all the public pension plans. In contrast, for the post-crisis period, when the employer contribution gap is increased at $t-1$, all the public pension plans (plans in 
both low and high funding levels) tend to decrease a share of equities at $t$ (columns (6) and (8)), the result which supports the risk management hypothesis. ${ }^{3}$ Overall, the regression results presented in the table suggest that the risktaking behavior of public pension plans has changed after the financial crisis of 2008.

Table 4: Regression Analysis of Public Pension Plan Risk-Taking Behavior by Funding Levels: Pre- and Post-Financial Crisis

\begin{tabular}{|c|c|c|c|c|c|c|c|c|}
\hline \multirow{3}{*}{$\begin{array}{c}\text { Dependent Variable: } \\
\text { Equity }_{t}\end{array}$} & \multicolumn{4}{|c|}{ Pre-Crisis (2001 to 2007) } & \multicolumn{4}{|c|}{ Post-Crisis (2008 to 2011) } \\
\hline & \multicolumn{2}{|c|}{$\begin{array}{c}\text { Low Funding Level } \\
\text { at } t-1^{\dagger}\end{array}$} & \multicolumn{2}{|c|}{$\begin{array}{c}\text { High Funding Level } \\
\text { at } t-1^{\dagger}\end{array}$} & \multicolumn{2}{|c|}{$\begin{array}{c}\text { Low Funding Level } \\
\text { at } t-1^{\dagger}\end{array}$} & \multicolumn{2}{|c|}{$\begin{array}{l}\text { High Funding Level } \\
\text { at } t-1^{\dagger}\end{array}$} \\
\hline & (1) & (2) & (3) & (4) & (5) & (6) & (7) & (8) \\
\hline ErContrGap $_{t-1}$ & $\begin{array}{l}-0.003 \\
(0.039)\end{array}$ & $\begin{array}{c}0.017 \\
(0.025)\end{array}$ & $\begin{array}{l}0.100 * * \\
(0.039)\end{array}$ & $\begin{array}{c}0.019 * * * \\
(0.005)\end{array}$ & $\begin{array}{c}0.072 \\
(0.070)\end{array}$ & $\begin{array}{c}-0.056 * * * \\
(0.017)\end{array}$ & $\begin{array}{c}0.011 \\
(0.069)\end{array}$ & $\begin{array}{c}-0.118 * * \\
(0.053)\end{array}$ \\
\hline $\operatorname{InvRet}_{t-1}$ & $\begin{array}{l}3.038 \\
(2.737)\end{array}$ & $\begin{array}{c}2.710 \\
(4.502)\end{array}$ & $\begin{array}{c}3.842 * * \\
(1.580)\end{array}$ & $\begin{array}{l}3.802^{*} \\
(2.022)\end{array}$ & $\begin{array}{l}-0.241 \\
(1.831)\end{array}$ & $\begin{array}{l}-1.118 \\
(0.714)\end{array}$ & $\begin{array}{l}-1.500 \\
(2.718)\end{array}$ & $\begin{array}{c}2.818 * * * \\
(0.895)\end{array}$ \\
\hline ActiveAnnuitant $_{t}$ & $\begin{array}{c}0.011 \\
(0.017)\end{array}$ & $\begin{array}{l}-0.025 \\
(0.024)\end{array}$ & $\begin{array}{r}0.014 * * \\
(0.007)\end{array}$ & $\begin{array}{l}-0.017 \\
(0.010)\end{array}$ & $\begin{array}{l}-0.015 \\
(0.019)\end{array}$ & $\begin{array}{l}0.196^{*} \\
(0.111)\end{array}$ & $\begin{array}{l}-0.004 \\
(0.010)\end{array}$ & $\begin{array}{c}-0.097 * \\
(0.050)\end{array}$ \\
\hline PlanSize $_{t}$ & $\begin{array}{l}-0.004 \\
(0.0080\end{array}$ & $\begin{array}{l}-0.048 \\
(0.046)\end{array}$ & $\begin{array}{l}0.013^{*} \\
(0.008)\end{array}$ & $\begin{array}{l}-0.094 \\
(0.078)\end{array}$ & $\begin{array}{l}-0.007 \\
(0.010)\end{array}$ & $\begin{array}{c}0.234 * * * \\
(0.062)\end{array}$ & $\begin{array}{l}-0.004 \\
(0.008)\end{array}$ & $\begin{array}{c}0.254 * * * \\
(0.082)\end{array}$ \\
\hline BoardComp $_{t}$ & $\begin{array}{l}0.092^{*} \\
(0.047)\end{array}$ & & $\begin{array}{l}0.074^{*} \\
(0.040)\end{array}$ & & $\begin{array}{c}0.226 * * * \\
(0.079)\end{array}$ & & $\begin{array}{c}0.068 \\
(0.062)\end{array}$ & \\
\hline Teacher $_{t}$ & $\begin{array}{c}0.002 \\
(0.024)\end{array}$ & & $\begin{array}{c}0.052 \\
(0.038)\end{array}$ & & $\begin{array}{c}0.078 \\
(0.051)\end{array}$ & & $\begin{array}{c}0.076 \\
(0.063)\end{array}$ & \\
\hline General $_{t}$ & $\begin{array}{l}0.0005 \\
(0.024)\end{array}$ & & $\begin{array}{l}0.065^{*} \\
(0.037)\end{array}$ & & $\begin{array}{l}0.083^{*} \\
(0.050)\end{array}$ & & $\begin{array}{c}0.054 \\
(0.060)\end{array}$ & \\
\hline InvCouncil $_{t}$ & $\begin{array}{r}0.050 * * \\
(0.021)\end{array}$ & & $\begin{array}{c}0.030 \\
(0.020)\end{array}$ & & $\begin{array}{l}-0.041 \\
(0.025)\end{array}$ & & $\begin{array}{c}0.017 \\
(0.026)\end{array}$ & \\
\hline Time fixed effects & Yes & Yes & Yes & Yes & Yes & Yes & Yes & Yes \\
\hline Plan fixed effects & No & Yes & No & Yes & No & Yes & No & Yes \\
\hline $\begin{array}{l}\text { Hausman test for model } \\
\text { specification: Prob }>\chi^{2}\end{array}$ & & 0.677 & & 0.018 & & 0.024 & & 0.021 \\
\hline Number of plans & 49 & 49 & 69 & 69 & 73 & 73 & 59 & 59 \\
\hline Number of observations & 170 & 170 & 293 & 293 & 196 & 196 & 134 & 134 \\
\hline $\mathrm{R}^{2}$ & 0.243 & 0.142 & 0.281 & 0.332 & 0.293 & 0.261 & 0.074 & 0.266 \\
\hline
\end{tabular}

$\dagger$ A high (low) funding level is categorized with a threshold of an $83 \%$ of actuarial funding ratio. Note: Numbers in parenthesis are robust standard errors, which are adjusted for plan clusters. ***, **, and * indicates significance at the $1 \%, 5 \%$, and $10 \%$ levels, respectively.

\section{CONCLUSION}

This paper examines public pension plans' risk-taking behavior by testing two contrasting hypotheses: risk transfer and risk management hypotheses. Public pension plan sponsors may have a moral hazard incentive in managing pension plan assets because taxpayers are ultimately responsible for underfunded plans. The argument is related to the risk transfer hypothesis. In contrast, public pension plan sponsors would prefer to reduce potential variation in employer contributions because unexpected increases in required contributions to public pension plans may have to reduce services for schools or police in a given state/municipal budget. This argument is related to the risk management hypothesis. Risk-taking behavior of public pension plans that could be explained by either hypothesis would be changed after the financial crisis of 2008 because most pension plans experienced a significant underfunding during the financial crisis. In this context, the paper investigates whether public pension plans' risktaking behavior has changed after the financial crisis.

Using the sample of 126 public pension plans for the period of 2001-2011, I find that public pension plans' risk-taking behavior has changed after the financial crisis of 2008. Before the financial crisis, public pension plan sponsors invest more in equities when a large required contribution is expected. In particular, this risk-taking behavior is observed among the plans that are in a high funding level in the previous year. The findings for the precrisis period are consistent with those documented by Pennacchi and Rastad (2011) and Mohan and Zhang (2011),

\footnotetext{
${ }^{3}$ Because the plan characteristics variables—plan size, plan types, and separate investment council—may not reflect unobserved plan characteristics, a model controlling for plan fixed effects is preferred to one without the effects. In addition, Hausman test results (reported in Tables 3 and 4) indicate that the model should include the plan fixed effects.
} 
supporting the risk transfer hypothesis. After the financial crisis, however, the plan sponsors' risk-taking behavior has changed to support the risk management hypothesis. The change in risk-taking behavior is observed across the plans regardless of their funding levels. Thus, the findings suggest that public pension plans' risk-taking behavior is not constant over time, but can be varied depending on market conditions.

\section{AUTHOR INFORMATION}

Youngkyun Park, Ph.D., Assistant Professor of Finance, College of Business and Economics, University of Idaho, 875 Perimeter Drive MS 3161, Moscow, ID 83844-3161, USA. E-mail: youngpark@uidaho.edu

\section{REFERENCES}

1. Bader, L. N., \& Gold, J. (2007). The case against stock in public pension funds. Financial Analysts Journal, 63(1), 55-62.

2. Brainard, K. (2008). Public fund survey: Summary of findings for FY 2007. National Association of State Retirement Administrators.

3. Brainard, K. (2010). Public fund survey: Summary of findings for FY 2009. National Association of State Retirement Administrators.

4. Epple, D., \& Schipper, K. (1981). Municipal pension funding: A theory and some evidence. Public Choice, 37(1), 141-178.

5. Giertz, J., \& Papke, L. E. (2007). Public pension plans: Myths and realities for state budgets. National Tax Journal, 60(2), 305-323.

6. Gold, J. (2003). Risk transfer in public pension plans. In O. S. Mitchell, \& K. Smetters (Eds.), The pension challenge: Risk transfers and retirement income security (pp. 102-115). Oxford: Oxford University Press.

7. Government Accountability Office. (2010a, August). State and local government pension plans: Governance practices and long-term investment strategies have evolved gradually as plans take on increased investment risk. Washington, DC.

8. Government Accountability Office. (2010b, July). State and local governments: Fiscal pressures could have implications for future delivery of intergovernmental programs. Washington, DC.

9. Inman, R. (1982). Public employee pensions and the local labor budget. Journal of Public Economics, 19(1), 49-71.

10. Lucas, D. J., \& Zeldes, S. P. (2009). Pensions and health care: Fiscal challenges for state and local governments. American Economic Review, 99(2), 527-532.

11. Mohan, N., \& Zhang, T. (2012). An analysis of risk-taking behavior for public defined benefit pension plans (Upjohn Institute Working Paper 12-179). Kalamazoo, MI: W.E. Upjohn Institute for Employment Research.

12. Munnell A. H., \& Soto, M. (2007). State and local pensions are different from private plans (No. 1). Chestnut Hill, MA: Center for Retirement Research at Boston College.

13. Munnell A. H., Aubry, J.-P., \& Hurwitz, J. (2013). How sensitive is public pension funding to investment returns? (No. 34). Chestnut Hill, MA: Center for Retirement Research at Boston College.

14. Munnell A. H., Aubry, J.-P., \& Muldoon, D. (2008). The financial crisis and state/local defined benefit plans (No. 8-19). Chestnut Hill, MA: Center for Retirement Research at Boston College.

15. National Association of State Retirement Administrators (NASRA). (2013, January). Public pension plan investment return assumptions - Updated January 2013.

16. National Conference on Public Employee Retirement System. (November 2008). The Advantages of using conventional actuarial approaches for valuing public pension plans (NCPERS Research Series).

Washington, DC.

17. Novy-Marx, R., \& Rauh, J. D. (2009). The liabilities and risks of state-sponsored pension plans. Journal of Economic Perspectives, 23(4), 191-210.

18. Novy-Marx, R., \& Rauh, J. D. (2011). Public pension promises: How big are they and what are they worth? Journal of Finance, 66(4), 1211-1249.

19. Park, Y. (2009). Public pension plan asset allocations. Employee Benefit Research Institute Notes, 30(4), 112. 
20. Pennacchi, G., \& Rastad, M. (2011). Portfolio allocation for public pension funds. Journal of Pension Economics and Finance, 10(2), 221-245.

21. Rauh, J. D. (2006). Investment and financing constraints: Evidence from the funding of corporate pension plans. Journal of Finance, 61, 33-71.

22. Rauh, J. D. (2009). Risk shifting versus risk management: Investment policy in corporate pension plans. Review of Financial Studies, 22(7), 2687-2733.

23. Rauh, J. D. (2010). Are state public pensions sustainable? Why the federal government should worry about state pension liabilities. National Tax Journal, 63(3), 585-602.

24. Rauh, J. D. (2009). Risk shifting versus risk management: Investment policy in corporate pension plans. Review of Financial Studies, 22(7), 2687-2733.

25. Sharpe, W. F. (1976). Corporate pension funding policy. Journal of Financial Economics, 3(3), 183-193.

26. Treynor, J. L. (1977). The principles of corporate pension finance. Journal of Finance, 32(2), 627-638. 